\title{
INCOME SITUATION OF AGRICULTURAL HOLDINGS COVERED BY THE AGRICULTURAL ACCOUNTING SYSTEM (FADN) IN EUROPEAN UNION COUNTRIES
}

\author{
Aleksander Grzelak ${ }^{\bowtie}$ \\ Poznań University of Economics and Business, Poland
}

\begin{abstract}
The main purpose of this research is to assess the income situation of agricultural holdings and identify the related trends in EU-23 countries. As shown by surveys, the incomes followed an average moderate upward trend over the 2004-2015 period. The income situation of agricultural holdings was concluded to vary strongly across EU-23 countries. Even though the existing extensive system of support stabilizes the level of incomes (and despite an increase in the level of subsidies), it does not eliminate the significant variation. Simultaneously, it was noted that per-hectare incomes (less subsidies) followed a slight downward trend in 2004 2015, which indicates once again the important contribution of subsidies to the income situation of agricultural holdings in EU countries. Agricultural holdings in "new" member states (except for the Czech Republic) achieve much lower incomes than EU-15 farms.
\end{abstract}

Keywords: income, agricultural holdings, Common Agricultural Policy, subsidies

\section{INTRODUCTION}

Agricultural income has long been a problem of interest to the scientific community (Czyżewski and Matuszczak, 2004; Szuba and Poczta, 2013; Zegar, 2008). Despite the relatively high amounts of support allocated to this sector, practical challenges continue to be encountered (support instruments). Therefore, the rationale behind the support for this sector is to ensure food and energy security, in broad terms, and to provide public goods. Also, agriculture becomes more and more dependent on the evolution of the EU's CAP mechanisms. On the other hand, the functioning of agriculture is increasingly driven by external determinants beyond the control of farm managers. This is due to the increased integration of global food markets (Rembeza and Seremak-Bulge, 2009) and - in the case of EU countries - to the crucial role of the institutional factor (CAP) (Giersz, 2011).

The literature dealing with agricultural incomes presents many research trends, notably including the one focused on the impact of CAP instruments (Hansen and Teuber, 2010; Schmid et al., 2006; Severini and Tantari, 2013). These studies show the importance of support policies for agricultural incomes. Interesting analyses are presented in a report by (Hill and Bradley, 2015). It includes a comprehensive assessment of the level and evolution of agricultural income and gives some recommendations for further changes in the CAP. A research by Runowski (2014) indicates that agricultural incomes grow faster in new Member States than in EU-15 countries. In turn, according to (Matthews, 2016), the significant dependence of the agricultural producers' economic situation on public support makes farming income in EU countries susceptible to changes in budget expenditures. He also pointed that in 2004-2013, direct payments in EU countries accounted for $47 \%$ of incomes,

\footnotetext{
PhD hab. Aleksander Grzelak, prof. UEP, Department of Macroeconomics and Agricultural Economics, Poznań University of Economics and Business, Al. Niepodległości 10 St., 61-875 Poznań, Poland, e-mail: agrzelak@interia.pl; https://orcid. org/0000-0002-4290-4740
} 
the share of other public transfers was $15 \%$ and the remaining $38 \%$ were related to market factors.

The increasing outbreaks of animal disease (BSE, foot-and-mouth disease, bird flu, ASF), environmental degradation due to the widespread use of chemicals, and the problem of agricultural incomes (as yet unresolved) have led to a reflection on the evaluation of the functioning of agricultural holdings. The farmers are caught in a vicious circle where an increase in food production beyond market demand leads to a reduction in farm product prices, and thus to a decrease in their incomes which fall below the average level for non-agricultural households. To defend themselves against these adverse developments, farmers increased their production volume through technological improvements which again resulted in overproduction and a drop in prices (Czyżewski, 2017). Despite the increase in farming intensity and agricultural productivity, their efforts failed to translate into an increase in incomes (Zegar, 2012).

In 2004-2015, some unprecedented fluctuations in agricultural prices took place, preceded by the global economic crisis. Therefore, a question arises on the factors behind the volatility of income in that period. The main purpose of this research is to assess the income situation of agricultural holdings and identify the related trends in EU-23 countries. This paper focuses on the main determinants of the phenomenon in question, i.e. subsidies that support incomes and agricultural product prices.

\section{RESEARCH METHODOLOGY}

The evaluation of changes in the economic situation of EU farms was based on aggregated results collected in the EU FADN (Farm Accountancy Data Network). The FADN focuses on commercial farms, i.e. the main beneficiaries of the Common Agricultural Policy, which account for at least $90 \%$ of standard output (SO) in the region or country concerned. Thus, they are representative of the economic and production performance of thousands of agricultural holdings which produced at least $90 \%$ of a country's standard agricultural output.

Selected based on data availability, the period covered by this analysis (2004-2015) was marked by the biggest enlargement of the EU. The analyses relied on a comparative study of the developments under consideration. Mean values, the coefficient of variation, the Pearson's correlation coefficient and trend equations were used. The analyses were carried out for EU-23 countries: EU members who joined in 2004 or earlier. Malta and Cyprus were excluded from this group due to the smallest resources of arable land in these countries compared to the entire study population (23). The arithmetic means of the features examined were estimated for each of the countries covered for the period 20042015 to enable comparative analyses between countries.

The evaluation of changes in the economic situation of EU farms was based on aggregated results collected in the EU FADN (Farm Accountancy Data Network). The FADN focuses on commercial farms, i.e. the main beneficiaries of the Common Agricultural Policy which account for at least $90 \%$ of standard output (SO) in the region or country concerned. Thus, they are representative of the economic and production performance of thousands of agricultural holdings which produced at least $90 \%$ of a country's standard agricultural output.

Selected based on data availability, the period covered by this analysis (2004-2015) was marked by the biggest enlargement of the EU. The analyses relied on a comparative study of the developments under consideration. Mean values, the coefficient of variation, the Pearson's correlation coefficient and trend equations were used. Malta and Cyprus were excluded from this group due to the smallest resources of arable land in these countries compared to the entire study population (23). The arithmetic means of the features examined were estimated for each of the countries covered for the period 2004-2015 to enable comparative analyses between countries.

\section{FINDINGS}

The economic performance of the agriculture sector depends on weather conditions which, combined with the low elasticity of agricultural production, results in prices being more volatile than production. As a consequence, the sector's response to changes in economic conditions is mainly reflected by the price volatility of agricultural products and it is one of the main determinants of economic situation of agricultural holdings. In 2004-2015, global food markets were affected by a high volatility in agricultural commodity prices (FAO, 2018) which clearly increased from 2006. Generally, in 2004-2015, agricultural commodity prices followed an upward trend; this is especially true for cereals (wheat) (Grzelak, 2016), and was particularly noticeable in 
2006-2011. Until 2008, the prices of agricultural products increased. Then, in 2009, there was a sharp decline, followed by growth (2009-2011), a stabilization period (2012-2013) and another decline (2014-2015). This situation determined the general conditions of the economic situation in agriculture. The results of fluctuations in agricultural product prices include crop failures and (due to market speculation) the growing demand for food and plant products for non-food purposes. Prices of agricultural products were found to respond strongly to changes in the global business outlook; this is especially true for wheat and oilseeds. The prices of these products respond more flexibly to changes in the supply-demand balance, and can therefore quickly catch up the declines (Kavallari et al., 2011).

In the study period (2004-2015), farm incomes in EU-23 countries followed an upward trend (Fig. 1) impacted by business cycle fluctuations. This is confirmed by a relatively high coefficient of correlation $(0.71)$ between income per hectare and the FAO index of agricultural commodity prices. The upward trend in incomes was mainly driven by the improvement in relative prices (which benefited the agriculture sector), and by direct and other payments which increased the most in the new EU Member States. Moreover, this increase can be partially attributed to an improvement in productive inputs (mainly including farm area).

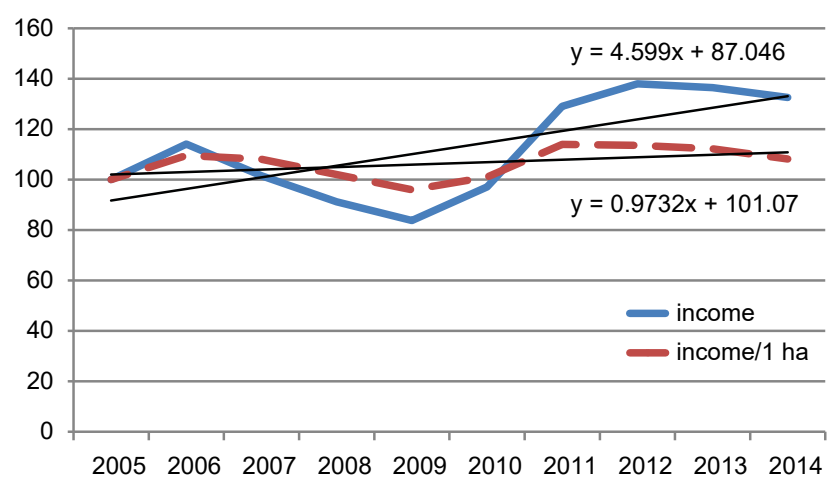

Fig. 1. Income per average EU-23 farm and per hectare of UAA, as reported by holdings covered by the FADN in 2005 $2014(2005=100)$. For each year, a three-period moving average was used

Source: own elaboration based on FADN data (http://europa. eu.int/comm/agriculture/rica/dwhource).
Note the considerable variation in the income situation of agricultural holdings across the countries studied, which is visible even for the moving average (Fig. 1).

The income growth rate, expressed as the slope of the regression equation, was higher for incomes per farm than for incomes per hectare. This is because of a slightly higher average area of UAA in relation to the productivity of the land factor. The tendency in incomes less subsidies per hectare of UAA was not clear (Fig. 2). Also because of the fact, that the coefficient of adjustment of trend line was very low $\left(\mathrm{R}^{2}=0.005\right)$.

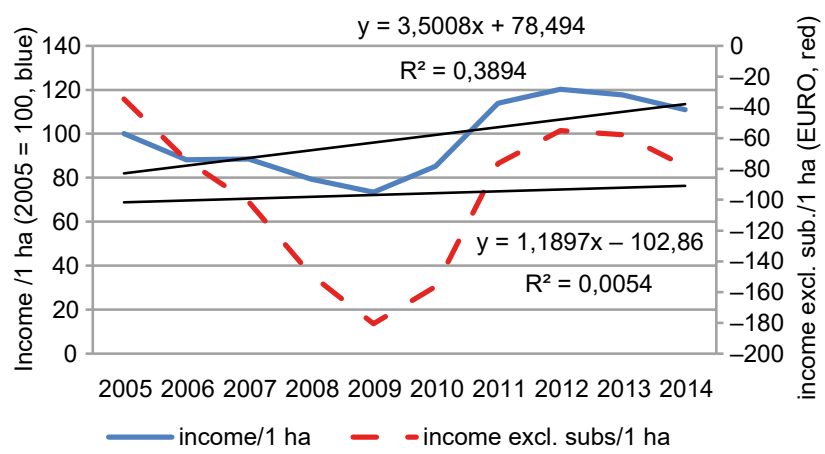

Fig. 2. Income per hectare of UAA in average agricultural holdings covered by the FADN in EU-23 countries in 20042015 (including and excluding subsidies) $(2004=100)$

Source: own elaboration based on FADN data (http://europa. eu.int/comm/agriculture/rica/dwhource).

These processes could suggest that the maximization of income of agricultural producers is mainly achieved by increasing the area of land and extending the existing support system. It may also partially result from the fact that the extended area of agricultural land is mainly used for cereal crops which are characterized by a lower intensity of production.

In 2013-2015, agricultural income increased in 17 out of 23 countries surveyed compared to the 20042015 period (Table 1). This was true for almost all new Member States (except for Latvia and Estonia), and was caused both by the base effect and by increased support (Runowski, 2014). The most substantial increases were recorded in Czech Republic and Hungary, and the largest decreases in Greece and Estonia. This suggests that changes in the income situation vary across countries. 
Table 1. Changes in income per hectare of UAA ( $\%$ and EUR) in EU-23 countries in agricultural holdings covered by the FADN between 2013-2015 and 2004-2006

\begin{tabular}{lcc}
\hline \multicolumn{1}{c}{ Countries } & $\mathrm{A}$ & $\mathrm{B}$ \\
\hline (BEL) Belgium & -5.57 & -66.55 \\
(CZE) Czech Republic & 144.38 & 139.0792 \\
(DAN) Denmark & 86.79 & 152.32 \\
(DEU) Germany & 14.31 & 57.48 \\
(ELL) Greece & -38.00 & -657.74 \\
(ESP) Spain & -17.31 & -118.40 \\
(EST) Estonia & -44.81 & -61.88 \\
(FRA) France & 1.25 & 4.81 \\
(HUN) Hungary & 181.07 & 247.35 \\
(IRE) Ireland & 20.247 & 84.96 \\
(ITA) Italy & 15.07 & 199.51 \\
(LTU) Lithuania & 0.94 & 2.32 \\
(LUX) Luxembourg & 25.33 & 133.98 \\
(LVA) Latvia & -9.62 & -17.73 \\
(NED) Netherlands & 36.04 & 452.28 \\
(OST) Austria & -2.47 & -19.07 \\
(POL) Poland & 22.61 & 87.22 \\
(POR) Portugal & 58.86 & 216.25 \\
(SUO) Finland & -24.24 & -97.70 \\
(SVE) Sweden & & 105.14 \\
(SVK) Slovakia* & & 17.88 \\
(SVN) Slovenia & & \\
\hline & & \\
(UKI) United Kingdom & & \\
\hline
\end{tabular}

A: percentage change in mean income between 2013-2015 and 2004-2006

B: difference in mean income (EUR) between 2013-2015 and 2004-2006

* In Slovakia, income was negative in 2004-2006. Countries which experienced an increase in income over the study period are highlighted in bold.

Source: own elaboration based on FADN data (http://europa. eu.int/comm/agriculture/rica/dwhource).
The economic performance of agricultural holdings varies strongly across EU countries (Table 2). In absolute terms, these differences result mainly from the scale of production, the efficiency of productive inputs and different production structures which translate into concentration and specialization processes.

In the agriculture of such countries as Slovakia or Czech Republic, the average area of farms (in the FADN group) is, respectively, 556 ha and 218 ha; Greece and Slovenia are at the other end of the spectrum with ca. 9 ha and ca. 11 ha, respectively. In 12 countries, the average level of subsidies was higher than the amount of incomes, and was similar to incomes in two more countries. This means that without support under the EU CAP, agricultural holdings in these countries would have negative average levels of income. Thus, even though the agriculture sectors had been part of EU structures for a relatively long time (which resulted in technical progress and in production concentration and specialization), they were unable to function autonomously without subsidies. On the other hand, note that direct support played a significant role in stabilizing the income situation despite the fact that fluctuations in farm incomes cannot be reduced (Phimister et al., 2004).

Therefore, it is proposed to establish an income insurance scheme for farmers to significantly reduce insurance premium rates and dampen fluctuations in agricultural incomes (Klimkowski, 2016). Note also that the ways of using subsidies differ in efficiency. In her research on New Member states, Baer-Nawrocka (2013) shows that Polish agriculture was exceptionally efficient in using the subsidies and in generating multiplier effects. The high volatility of income and the share of subsidies in income in Slovakia and Denmark are very interesting; all the more so since Denmark demonstrates relatively high productivity rates and extensive investments in agricultural fixed assets (Sobczyński, 2011). This can be explained by the fact that Danish agriculture is dominated by pig production which experienced substantial variation in profitability over the study period due to price fluctuations. Also, Denmark has a specific inheritance regime in respect of farms: the heir buys the farm from a farmer, most often through the use of credit, and the family members are accounted as paid labor input. Hence, this limits the level of income. In the case of Slovakia, this was due to a very low level of incomes at the beginning of the study period. Contributing to this was the relatively slow restructuring and adjustment of 
Grzelak, A. (2018). Income situation of agricultural holdings covered by the agricultural accounting system (FADN) in European Union countries. J. Agribus. Rural Dev., 4(50), 367-373. http://dx.doi.org/10.17306/J.JARD.2018.00424

Table 2. Selected characteristics of the income situation of EU-23 agricultural holdings covered by the FADN (mean level in 2004-2015)

\begin{tabular}{|c|c|c|c|c|c|c|c|}
\hline Countries & $\begin{array}{l}\text { Income } \\
\text { (EUR) }\end{array}$ & Income/ha & $\begin{array}{c}\text { Farm Net } \\
\text { Value Added/ } \\
\text { AWU (SE425) }\end{array}$ & $\begin{array}{l}\text { Coefficient of } \\
\text { income varia- } \\
\text { tion (a) }\end{array}$ & $\begin{array}{l}\text { UAA } \\
\text { (ha) }\end{array}$ & $\begin{array}{l}\text { Share of total } \\
\text { subsidies in } \\
\text { income } \\
(\%)\end{array}$ & $\begin{array}{c}\text { Share of public } \\
\text { good payments (b) } \\
\text { in total subsidies } \\
(\%)\end{array}$ \\
\hline Belgium & 52000.4 & 1117.0 & 39693.7 & 14.77 & 46.6 & 47 & 9.09 \\
\hline Czech Republic & 34691.2 & 158.8 & 15555.4 & 40.95 & 218.4 & 211 & 22.13 \\
\hline Denmark & 15157.7 & 166.1 & 66061.2 & 225.92 & 91.3 & 233 & 4.18 \\
\hline Germany & 36027.0 & 434.3 & 34342.8 & 24.19 & 82.9 & 95 & 13.39 \\
\hline Greece & 11522.5 & 1333.2 & 12259.9 & 13.08 & 8.6 & 57 & 12.11 \\
\hline Spain & 22036.4 & 581.1 & 21354.1 & 15.94 & 37.9 & 42 & 8.85 \\
\hline Estonia & 15835.1 & 132.1 & 12790.4 & 39.80 & 119.8 & 145 & 30.79 \\
\hline France & 34235.4 & 403.1 & 31474.8 & 25.22 & 84.9 & 92 & 10.85 \\
\hline Hungary & 13269.4 & 263.3 & 15196.0 & 45.20 & 50.4 & 111 & 13.44 \\
\hline Ireland & 19501.5 & 425.8 & 21691.0 & 18.76 & 45.8 & 104 & 26.5 \\
\hline Italy & 22499.5 & 1354.2 & 23469.1 & 18.97 & 16.6 & 30 & 13.95 \\
\hline Lithuania & 12100.2 & 285.7 & 7309.9 & 29.23 & 42.3 & 81 & 20.42 \\
\hline Luxembourg & 47338.2 & 607.0 & 34596.5 & 23.08 & 78.0 & 122 & 33.77 \\
\hline Latvia & 10975.4 & 166.5 & 7307.7 & 20.22 & 65.9 & 131 & 27.36 \\
\hline Netherlands & 48168.7 & 1382.5 & 46263.7 & 32.81 & 34.8 & 37 & 12.54 \\
\hline Austria & 25005.0 & 809.0 & 20905.5 & 14.09 & 30.9 & 80 & 47 \\
\hline Poland & 7986.3 & 439.4 & 6019.3 & 22.77 & 18.2 & 62 & 17.99 \\
\hline Portugal & 11226.4 & 445.1 & 8929.0 & 22.88 & 25.2 & 65 & 24.85 \\
\hline Finland & 20282.6 & 377.0 & 23972.3 & 14.95 & 53.8 & 239 & 46.38 \\
\hline Sweden & 17208.0 & 178.4 & 30173.3 & 41.35 & 96.5 & 209 & 31.84 \\
\hline Slovakia & -6781.5 & -12.2 & 8242.3 & -656.84 & 556.1 & - & 30.78 \\
\hline Slovenia & 5675.2 & 533.5 & 3596.5 & 22.54 & 10.6 & 137 & 36.74 \\
\hline United Kingdom & 42381.7 & 274.0 & 36481.8 & 24.72 & 154.7 & 101 & 19.67 \\
\hline $\begin{array}{l}\text { Mean } \\
\text { (Median) }\end{array}$ & $\begin{array}{c}22536.6 \\
(19501.7)\end{array}$ & $\begin{array}{c}515.4 \\
(425.8)\end{array}$ & $\begin{array}{c}22942.9 \\
(21354.1)\end{array}$ & $\begin{array}{c}14.77 \\
(22.88)\end{array}$ & $\begin{array}{c}85.7 \\
(50.4)\end{array}$ & $\begin{array}{l}110.5 \\
(98)\end{array}$ & $\begin{array}{c}22.37 \\
(-20.42)\end{array}$ \\
\hline $\begin{array}{l}\text { Coefficient of } \\
\text { variation }\end{array}$ & 67.44 & 79.8 & 66.7 & - & 132.9 & 4225.7 & -20.42 \\
\hline
\end{tabular}

coefficient of variation = standard deviation / mean; public good payments: set-aside subsidies, agri-environmental payments, LFA payments and other subsidies for rural development

Source: own elaboration based on FADN data (http://europa.eu.int/comm/agriculture/rica/dwhource). 
Slovak farms, in the vast majority large farms, to the new farming conditions. Conversely, in the agriculture of southern EU countries, income volatility was relatively lower because of prices of fruits and vegetables being relatively more stable (a factor of great importance to agricultural production in these countries).

In turn, the highest income per hectare of UAA was recorded in countries which demonstrate high intensity of production (Belgium, the Netherlands) or are dominated by horticultural output (Greece, Italy). Note that in the case of agricultural holdings from Italy, especially from Greece, the absolute level of average agricultural incomes is not high and is below the average recorded in non-agricultural sectors of economy, due to low average area of farmland.

However, the highest labor productivity, in terms of value added per FTE, was recorded in the Benelux, Denmark and United Kingdom. But if subsidies were set aside, the Belgian and Dutch farms would be the most efficient. This is due to a high degree of agricultural production intensity, specialization and concentration in these countries. Also significant was their specialization in the production of fruits and vegetables (or cattle and poultry).

In the case of agricultural holdings from the new Member States, a significantly (almost three times) lower level of agricultural income was recorded. This is due to smaller amounts of production resources per farm, less sophisticated specialization processes, lower assets-to-labor ratios and lower subsidies. Czech farms are an exception due to high manufacture volumes, high productivity levels, and a greater importance of leases (Davidova and Latruffe, 2007). The negative level of income in Slovakian farms is a noteworthy finding. This is related to the fact that Slovakian farms report relatively high amounts of depreciation and wage costs (hired employees) while having relatively low levels of production efficiency per hectare. Generally, in the study period, incomes were higher than the amount of subsidies only in two new Member States (Poland and Lithuania) out of the eight countries surveyed (Grzelak, 2016).

The reduction of the farm's environmental impact, and support for the creation of public goods was compensated by subsidies to public goods. They had the largest share in the total amount of subsidies in Austria, Finland and Slovenia. In contrast, the contribution of public good subsidies was generally low in countries with intensive farming. In the next EU budgetary perspective (2020-2027), it would be advisable to create the conditions for heightening the share of this type of subsidies, especially in countries with a strong environmental impact.

\section{SUMMARY AND CONCLUSIONS}

The income situation of agricultural holdings in the EU23 varies considerably across countries and depends on the scale of production, natural conditions and resources, business cycle factors, including agricultural commodity prices. While the existing extensive system of support stabilizes the level of incomes, it does not eliminate the significant variation. However, the absence of support would result in even more significant fluctuations in income. In the study period (2004-2015), of the 23 EU countries surveyed, 12 reported incomes below the level of support. In two more countries (France and Germany), subsidies and incomes were at a comparable level. It means that without the CAP, a significant part of Union agriculture would be unprofitable, and thus its products would be uncompetitive (in terms of pricing) in the global food market. On the other hand, it should be emphasized that average incomes followed a moderate upward trend in the study period. It was stronger for incomes per farm than for incomes per hectare of UAA because the area of land increased faster than land productivity.

Moreover, it can be concluded (in the light of this research and the literature review) that there is margin for improving the income situation of the "new" member states through further concentration of land resources, and also because the costs of productive inputs are lower, the integration processes are underdeveloped and resource productivity continues to be relatively low. In turn, the "old" member countries face a more complicated situation which the author believes to depend increasingly more on qualitative factors.

Agricultural holdings in new Member States (except for the Czech Republic) achieve significantly lower incomes compared to farms of "old" member countries. This is related to a smaller scale of production and differences in the assets-to-labor ratio and amount of subsidies. It can be expected that in a context of growing environmental requirements for agricultural production (reduction of intensity), farm managers will try to improve their income situation by further extending their farmland through purchase or lease. 


\section{SOURCE OF FINANCING}

Statutory research of the Poznań University of Economics and Business.

\section{REFERENCES}

Baer-Nawrocka, A. (2013). Wpływ Wspólnej Polityki Rolnej na efekty dochodowe w rolnictwie nowych krajów członkowskich Unii Europejskiej [The influence of Common Agricultural Policy on agricultural incomes effects in the new member countries of the European Union]. Pol. Eur. Fin. Market., 9(58), 34-44 [in Polish].

Czyżewski, B. (2017). Kierat rynkowy w europejskim rolnictwie [Market treadmill in the European agriculture]. Warszawa: wyd. Nauk. PWN [in Polish].

Czyżewski, A., Henisz-Matuszczak, A. (2004). Rolnictwo Unii Europejskiej i Polski. Studium porównawcze struktur wytwórczych i regulatorów rynków rolnych [Agriculture of the European Union and Poland. A comparative study of productive structures and regulators of agricultural markets]. Poznań: Wyd. AE w Poznaniu [in Polish].

Davidova, S., Latruffe, L. (2007). Relationships between Technical Efficiency and Financial Management for Czech Republic Farms. J. Agric. Econ., 58, 2, 269-288. https://doi.org/10.1111/j.1477-9552.2007.00109.x

FAO (2018). World Food Situation. Retrieved April 19th 2018 from: http://www.fao.org/worldfoodsituation/foodpricesindex/en/

Giersz, Z. (2011). Instrument stabilizacji dochodów - nowy instrument zarządzania ryzykiem w perspektywie Wspólnej Polityki Rolnej po 2013 r. [The income stabilization instrument - a new risk management instrument in the perspective of the Common Agricultural Policy after 2013]. Warszawa: FAPA Sekcja Analiz Ekonomicznych Polityki Rolnej [in Polish].

Grzelak, A. (2016). The economic situation of agricultural holdings in the European Union after 2004. In: Proceedings - Hradec Economic Days (pp. 219-225). Hradec Kralove: University of Hradec Kralove.

Hansen, H., Teuber, R. (2010). Assessing the impacts of EU's common agricultural policy on regional convergence: sub-national evidence from Germany. Appl. Econ., 43, 26, 3755-3765. https://doi.org/10.1080/00036841003724395

Hill, B., Bradley, D. (2015). Comparison of farmers` incomes in the EU Member States, Study for the European Parliaments Committee on Agriculture and Rural Development. Retrived April 12th 2018 from: http://www.europarl. europa.eu/RegData/etudes/STUD/2015/540374/IPOL_ STU\%282015\%29540374_EN.pdf
Kavallari, A., Fellman, T., Gay, S. (2011). Shocks in economic growth - shocking effects on agricultural markets? Paper prepared for the EAAE Congres in Zurich (pp. 4-9).

Klimkowski, C. (2016). Farm income stabilization effectiveness and income stabilization tool. J. Agribus. Rural Dev., 3(41), 309-318. DOI: 10.17306/JARD.2016.58

Matthews, A. (2016). The dependence of EU farm income on public support. Retrieved April 11 2018 from: http:// capreform.eu/the-dependence-of-eu-farm-income-onpublic-support/

Phimister, E., Roberts, D., Gilbert, A. (2004). The Dynamics of Farm Incomes. J. Agric. Econ., 55(2), 197-220.

Rembeza, J., Seremak-Bulge, J. (2009). Ewolucja podstawowych rynków rolnych i jej wpływ na transmisję cen w latach 1990-2008 [The evolution of basic agricultural markets and its impact on the transmission of prices in the years 1990-2008] (pp. 75-132). Warszawa: IERiGŻ [in Polish].

Runowski, H. (2014). Kształtowanie się dochodów gospodarstw rolnych w Unii Europejskiej [Formation of farm incomes in the European Union]. Pr. Nauk. Uniw. Ekon. Wroc., 361, 195-205 [in Polish]. DOI: 10.15611/ pn.2014.361.20

Schmid, E., Sinabell, F., Hofreither, M. (2006). Direct payments of the CAP-distribution across farm holdings in the EU and effects on farm household incomes in Austria. Wien: Univ. für Bodenkultur Wien, Inst. für Nachhaltige Wirtschaftsentwicklung.

Severini, S., Tantari, A. (2013). The Effect of the EU Farm Payments Policy and its Recent Reform on Farm Income Inequality. J. Polic. Model., 35(2), 212-227. DOI: https:// doi.org/10.1016/j.jpolmod.2012.12.002

Sobczyński, T. (2011). Ocena możliwości rozwojowych gospodarstwa rolniczych Unii Europejskiej na podstawie inwestycji netto w latach 1998-2008 [Evaluation of development opportunities of the European Union agricultural holdings based on net investment in 1998-2008]. Folia Pom. Univ. Technol. Stein. Oecon., 65, 145-155 [in Polish].

Szuba, E., Poczta, W. (2013). Próba oceny wpływu wspólnej polityki rolnej na zmiany sytuacji ekonomicznej w rolnictwie krajów środkowo-wschodniej Europy [An attempt to assess the impact of the common agricultural policy on changes in the economic situation in agriculture in Central and Eastern Europe]. Rocz. Nauk. SERiA, 5(15), 293-299 [in Polish].

Zegar, J. (2008). Dochody w rolnictwie w okresie transformacji i integracji europejskiej [Incomes in agriculture in the period of transformation and the European integration]. Warszawa: IERiGŻ-PIB [in Polish].

Zegar, J. (2012). Współczesne wyzwania rolnictwa [Contemporary agriculture challenges]. Warszawa: Wyd. Nauk. PWN [in Polish]. 